\title{
JARINGAN OTOT RANGKA Sistem membran dan struktur halus unit kontraktil
}

\author{
Sunny Wangko \\ Bagian Anatomi-Histologi Fakultas Kedokteran Universitas Sam Ratulangi Manado \\ Email: sunnywangko@yahoo.com
}

\begin{abstract}
There are three main components of skeletal muscle: connective tissue, muscle tissue, and membrane system. The connective tissue protects the muscle fibers and separate them into fasicles. The skeletal muscle consists of paralel muscle fibers with their myofibrils which are composed by smaller contractile units, thick myofilaments and thin myofilaments. The membrane system consists of sarcolemma, transverse tubules (TT), foot structure, and sarcoplasmic reticulum (SR) with its cisternae. Depolarization of the sarcolemma spreads to TT, foot structure, and SR, resulting in the release of $\mathrm{Ca}^{2+}$ ions from SR. These ions trigger the formation of cross bridges to begin a contraction.
\end{abstract}

Keywords: sarcolemma, $\mathrm{T}$ tubule, sarcoplasmic reticulum, thick myofilament, thin myofilament

\begin{abstract}
Abstrak: Terdapat tiga komponen utama jaringan otot rangka, yaitu: jaringan ikat, jaringan otot seran lintang, dan sistem membran. Jaringan ikat berfungsi melindungi serat-serat otot dan memisahkannya atas berkas-berkas otot. Jaringan otot rangka tersusun atas serat-serat otot yang bherjalan sejajar dengan miofibrilnya yang terdiri atas unit kontraktil yang lebih kecil yaitu miofilamen tebal dan tipis. Sistem membran terdiri atas sarkolema dimana terjadinya depolarisasi yang paling awal dan dihantarkan ke dalam serat otot melalui tubulus $\mathrm{T}$, struktur kaki pada daerah triad, dan sisterna terminalis yang selanjutnya memicu pelepasan ion $\mathrm{Ca}^{2+}$ dari retikulum sarkoplasma. Ion $\mathrm{Ca}^{2+}$ merupakan pemicu untuk pembentukan jembatan silang yang mengawali suatu kontraksi otot.
\end{abstract}

Kata kunci: sarkolema, tubulus T, retikulum sarkoplasma, filamen tebal, filamen tipis

Tulang dan sendi membentuk rangka tubuh (skeleton), tetapi tidak dapat menghasilkan pergerakan sendiri. Pergerakan dihasilkan oleh pergantian kontraksi dan relaksasi otot, dimana terjadi perubahan energi kimia (ATP) menjadi energi mekanik.

Jaringan otot menyusun $40-50 \%$ dari berat badan total. Secara umum fungsi jaringan otot ialah untuk pergerakan, stabilisasi posisi tubuh, mengatur volum organ dan termogenesis; diperkirakan $85 \%$ panas tubuh dihasilkan oleh kontraksi otot. Sifat jaringan otot ialah eksitabilitas/ iritabilitas, dapat berkontraksi, dapat diregang tanpa merusak jaringannya pada batas tertentu, dan elastisitas. Berdasarkan ciri-ciri histologik, lokasi serta kontrol sistem saraf dan endokrin, jaringan otot dikelompokkan atas jaringan otot rangka, otot jantung, dan otot polos.

Jaringan otot rangka terutama melekat pada tulang dan berfungsi menggerakkan bagian-bagian skeleton. Jaringan otot ini tergolong otot bercorak/striated karena pada pengamatan mikroskopik jaringan ini memperlihatkan adanya garis/pita gelapterang bergantian. Jaringan otot rangka bersifat volunter karena berkontraksi dan berelaksasi di bawah kontrol kesadaran. Jaringan otot jantung juga tergolong otot bercorak tetapi kontraksinya tidak di bawah kontrol kesadaran. 


\section{GAMBARAN HISTOLOGIK UMUM JARINGAN OTOT RANGKA}

Gambaran histologik umum jaringan otot rangka memperlihatkan tiga komponen dasar yang menyusun otot rangka, yaitu: jaringan ikat, jaringan otot, dan sistem membran.

Komponen jaringan ikat terdiri atas (dari luar ke dalam) fasia superfisialis, fasia profunda, epimisium, perimisium, dan endomisium.

Gambaran histologik jaringan otot rangka memperlihatkan beratus-ratus sampai beribu-ribu serat panjang, berbentuk silindrik, yang disebut serat otot (fiber). Serat otot terletak sejajar satu dengan lainnya. Diameter serat berkisar 10$100 \mu \mathrm{m}$ dan panjang $100 \mu \mathrm{m}$, tetapi dapat mencapai $30 \mathrm{~cm}$. Serat otot rangka berasal dari fusi banyak sel kecil semasa embrio; oleh karena itu setiap serat otot mempunyai banyak inti. Inti terletak di tepi, tepat di bawah sarkolema, bebas dari elemen kontraktil (Gambar 1). Mitokondria terletak dalam deretan di seluruh serat otot, berdekatan dengan protein otot yang menggunakan ATP untuk kontraksi (Gambar 2). Secara mikoskopik dengan pembesaran tinggi pada sarkoplasma terlihat adanya benang-benang halus yang disebut miofibril, terletak memanjang dan tersusun sedemikian rupa sehingga memperlihatkan pita gelap terang bergantian; hal ini yang menyebabkan serat otot tampak bercorak garis melintang.

Sistem membran terdiri dari sarkolema, tubulus transversal/tubulus $\mathrm{T}$, dan retikulum sarkoplasma .

\section{SISTEM MEMBRAN}

Sarkolema merupakan membran plasma dari serat otot yang membungkus sarkoplasma. Sarkolema serat otot rangka tersusun oleh plasmalema dan membran basalis, sedangkan membran basalis sendiri terdiri dari lamina basalis dan lamina retikularis; oleh karena itu sarkolema disebut juga trilaminar cell membrane.
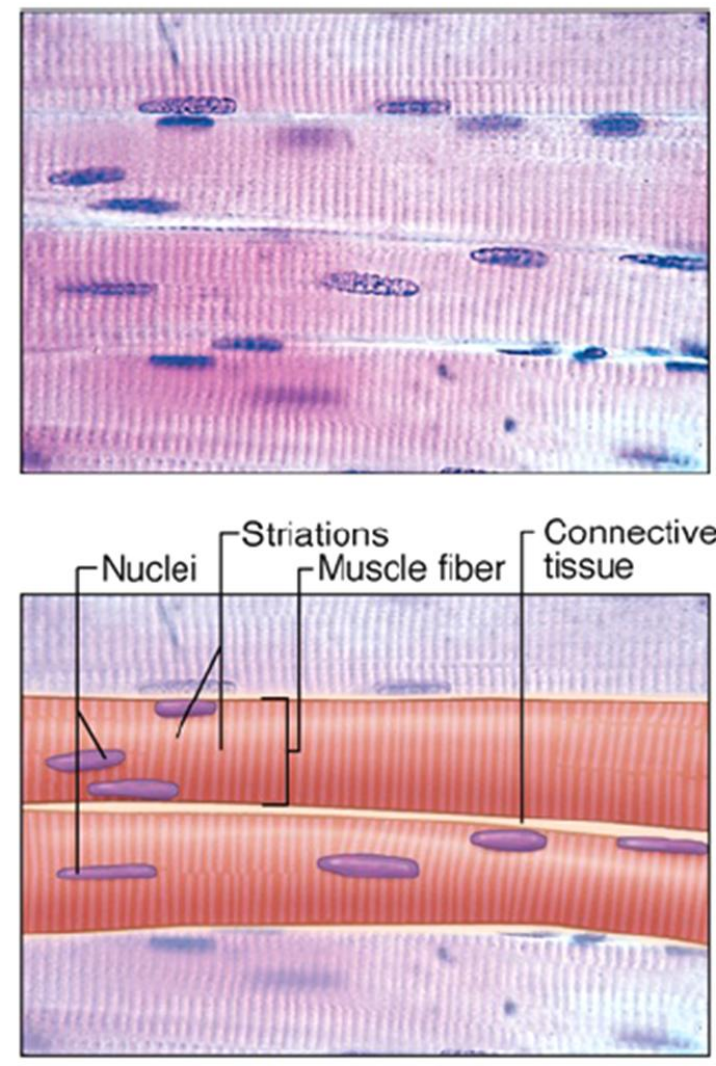

Gambar 1. Gambaran mikroskopik dan gambaran skematik jaringan otot rangka. Tampak corak bergaris melintang baik pada gambaran mikroskopik maupun skematik. Sumber: Mescher AL, 2010. ${ }^{9}$

Tubulus T (TT) merupakan invaginasi sarkolema, yang memungkinkan TT berhubungan dengan luar serat (ekstrasel). TT menembus serat otot secara vertikal terhadap RS dan miofilamen. Pada membran TT terdapat reseptor dihidropiridin yaitu suatu voltage gated calcium channel. Pada kedua sisi TT terdapat sisterna terminalis yaitu pelebaran ujung RS. Tubulus $\mathrm{T}$ dan kedua sisterna terminalis disebut triad (Gambar 2).

Retikulum sarkoplama (RS) merupakan sistem membran intrasel, berisi cairan, yang melingkari setiap miofibril (Gambar 2). RS merupakan bentuk khusus retikulum endoplasmik yangberfungsi antara lain untuk menyimpan ion $\mathrm{Ca}^{2+}$. Pada $\mathrm{RS}$ terekspresi tiga jenis protein: sarcolendoplasmic $\mathrm{Ca}^{2+}$-ATPase (SERCA), reseptor rianodin (saluran pelepas $\mathrm{Ca}^{2+}$, 
$\mathrm{Ca}^{2+}$ release channel) dan calsequestrin (protein pengikat $\mathrm{Ca}^{2+}$ ). Pada otot rangka manusia, triad terdapat pada tepi miofibril, terletak pada batas pita A dan I. Membran TT dan sistena terminalis dipisahkan oleh suatu celah. Merentang pada celah tersebut terdapat struktur yang disebut kaki (junctional feet) yang merupakan saluran pelepas $\mathrm{Ca}^{2+}$ dari $\mathrm{RS}$ (reseptor rianodin) (Gambar 3).

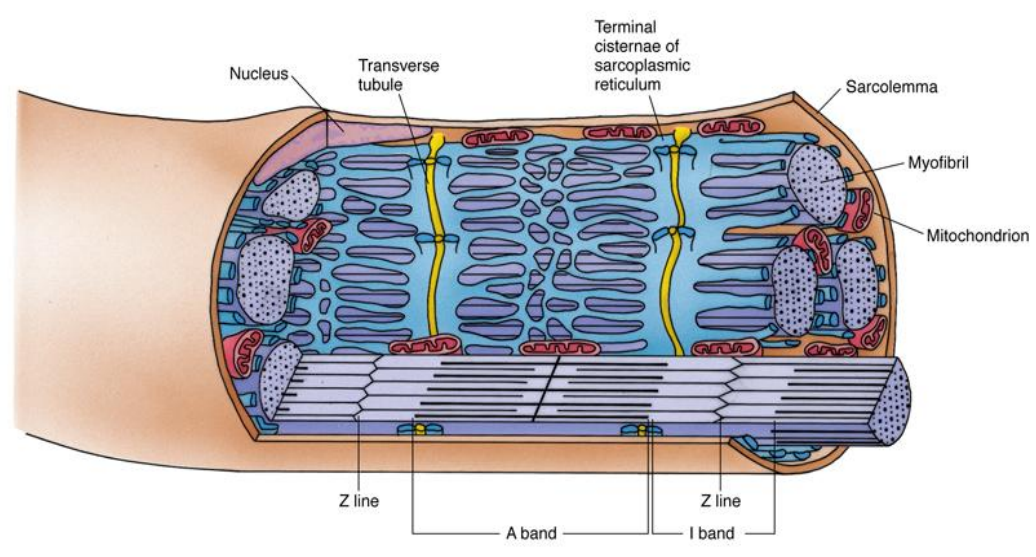

Gambar 2. Organisasi triad dan sarkomer pada otot rangka. Triad terletak pada batas pita A dan I, yang memungkinkan pelepasan segera dari ion $\mathrm{Ca}^{2+}$ dari sisterna terminalis $\mathrm{RS}$ tepat pada daerah dimana interaksi filamen tebal dan tipis dapat menghasilkan pemendekan sarkomer. Mitokondria tampak di tepi miofibril. Sumber: Gartner LP, Hiatt JL, 2007. ${ }^{5}$

\section{MIOFIBRIL， MIOFILAMEN， DAN PROTEIN KONTRAKTIL}

Miofibril merupakan elemen kontraktil jaringan otot rangka, berdiameter 1-2 $\mu \mathrm{m}$, dan terdiri dari struktur yang lebih halus lagi yaitu miofilamen/filamen. Terdapat tiga jenis filamen yaitu filamen tebal, filamen tipis, dan filamen elastin. Pada miofibril, filamen tersusun dalam bentuk sarkomer. Sarkomer dibatasi oleh dua garis/lempeng Z. Pada sebuah sarkomer terdapat daerah gelap yaitu pita A (anisotropik) yang dibentuk oleh filamen tebal dan sebagian filamen tipis sebelah menyebelah. Daerah yang lebih terang yaitu pita I (isotropik) dibentuk oleh bagian sisa filamen tipis, tanpa filamen tebal. Garis $\mathrm{Z}$ melewati titik tengah pita I. Pada tengah pita A terdapat daerah yang lebih terang, zone $\mathrm{H}$, yang dibagi dua oleh garis $\mathrm{M}$ (Gambar 4A).

Terdapat dua jenis protein kontraktil otot yaitu miosin dan aktin. Filamen tebal terutama tersusun oleh miosin sedangkan filamen tipis terutama oleh aktin. Bagian ekor miosin menuju garis $\mathrm{M}$ di tengah sarkomer. Kepala miosin yang membentuk jembatan silang (cross bridge) akan menuju filamen tipis pada saat kontraksi. Bagianbagian batang miosin terletak sejajar, membentuk badan filamen tebal. Tonjolan kepala miosin dari batang filamen tersusun dalam bentuk spiral (Gambar 4A, C, D).

Filamen tipis tersusun oleh aktin dan dua jenis protein regulator yaitu tropomiosin dan troponin. Molekul aktin berbentuk ginjal, bergabung membentuk satu rantai filamen aktin, yang berpilin seperti spiral ganda. Pada setiap molekul aktin terdapat tempat pengikat miosin (tempat aktif) dimana akan melekat jembatan silang (kepala miosin). Dalam keadaan relaksasi otot, tropomiosin menutupi tempat pengikat miosin pada aktin sehingga menghambat perlekatan jembatan silang (Gambar 4 A, C). 


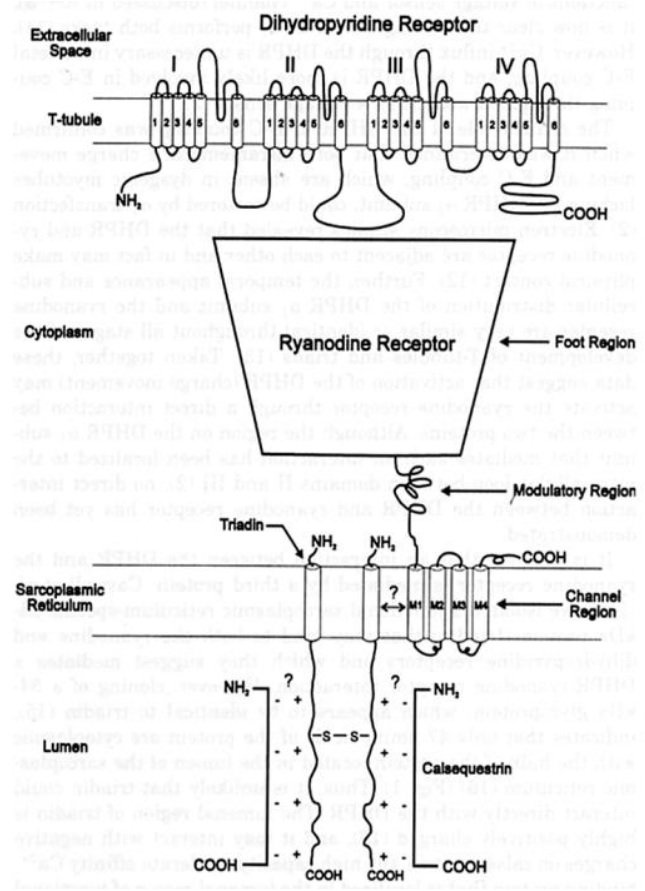

Gambar 3. Gambar skematis daerah triad. Tampak tubulus $\mathrm{T}$ yang merupakan lanjutan sarkolema (berhubungan dengan ruang ekstrasel), struktur kaki (foot region), dan retikulum sarkoplasma. Sumber: McPherson PS, Campbell KP, $1993{ }^{8}$

\section{HISTOFISIOLOGI KONTRAKSI DAN RELAKSAASI OTOT}

Mekanisme kontraksi otot yang dianut sekarang ialah sliding filament mechanism yang dikemukakan oleh Jean Hanson dan Hugh Huxley tahun 1950. Pada kontraksi otot terjadi pergeseran miofilamen tebal dan tipis serta pemendekan sarkomer dan serat otot, tetapi tidak terjadi pemendekan miofilamen (Gambar 4A).

Pada saat akan dimulainya kontraksi otot rangka, ion $\mathrm{Ca}^{2+}$ dilepaskan ke dalam sarkoplasma melalui saluran pelepas $\mathrm{Ca}^{2+}$ (reeptor rianodin) dan akan secara efisien ditranspor kembali ke dalam RS oleh kerja SERCA pada membran RS saat relaksasi otot. RS akan menyimpan $\mathrm{Ca}^{2+}$ yang terikat pada protein calsequestrin. Oleh karena $\mathrm{Ca}^{2+}$ didaur ulang sedemikian efisien maka pada kontraksi otot rangka (short term) tidak diperlukan $\mathrm{Ca}^{2+}$ ekstrasel.

RS otot rangka merupakan tempat penyimpanan ion $\mathrm{Ca}^{2+}$ dalam jumlah besar.
Transpor ion ini melalui membran RS diatur oleh dua molekul: reseptor rianodin dan $\mathrm{Ca}^{+2}$-ATPase. Sinyal pelepasan ion $\mathrm{Ca}^{2+}$ diawali oleh adanya depolarisasi membran sarkolema yang dihantarkan ke TT. Aksi potensial akan meluas ke RS melalui struktur kaki pada daerah triad dan memicu pelepasan ion $\mathrm{Ca}^{2+}$ dari $\mathrm{RS}$ melalui saluran pelepas $\mathrm{Ca}^{2+}$ ke sarkoplasma di sekitar miofilamen tebal dan tipis.
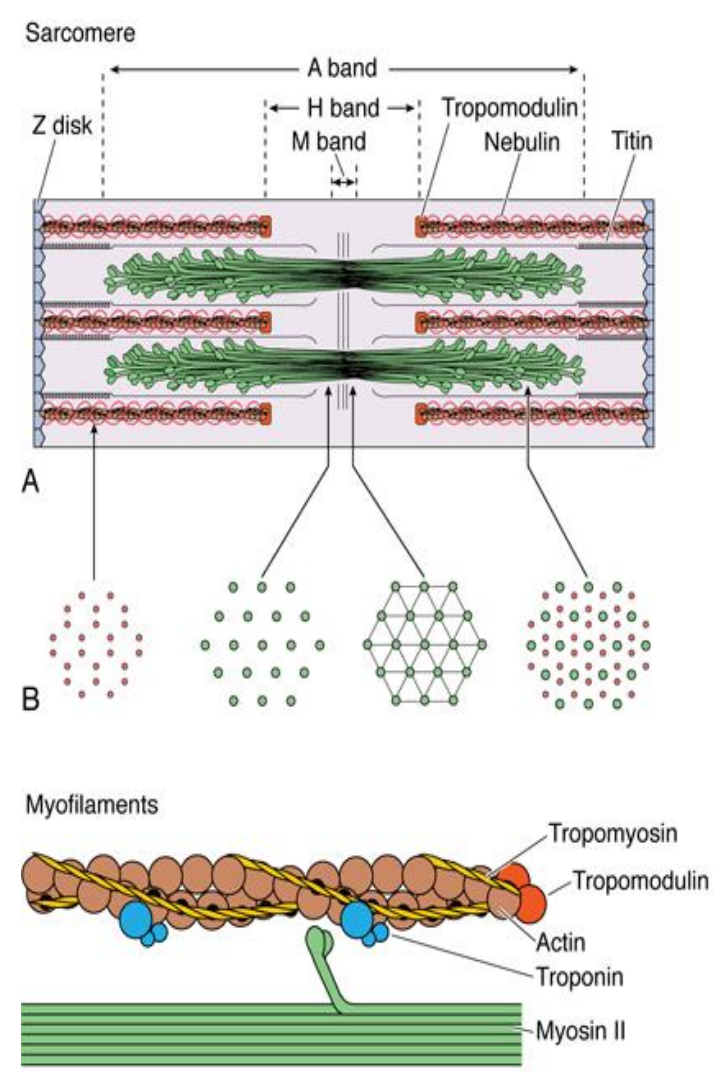

C

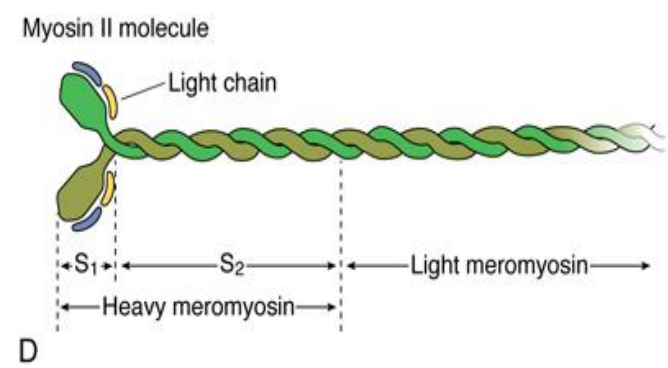

Gambar 4. Sarkomer dan komponennya. A) Molekul miosin yang tersusun antiparalel. B) Potongan melintang sarkomert pada daerahdaerah tertentu. C) Miofilamen tipis dan tebal. D) Molekul miosin II. Sumber: Gartner LP, Hiatt JL, 2007. ${ }^{5}$ 

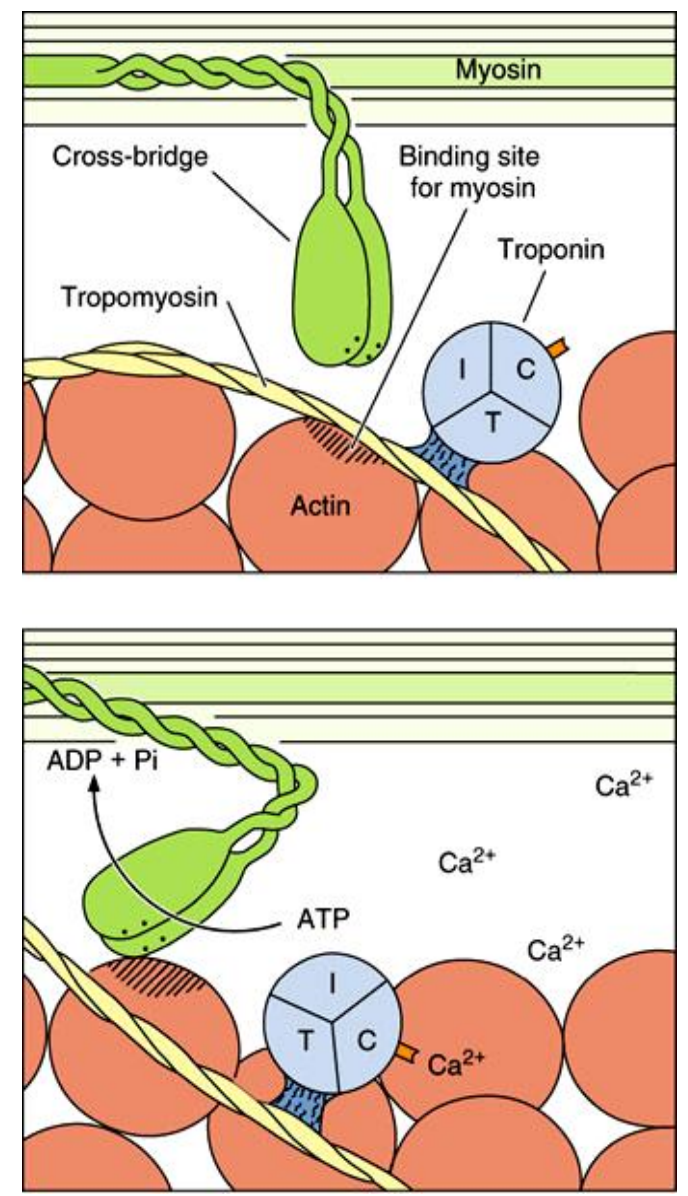

Gambar 5. Kontraksi otot yang diawali oleh terikatnya $\mathrm{Ca}^{2+}$ ke troponin C. Kepala miosin berikatan dengan aktin dan terjadi hidrolisis ATP menjadi ADP yang menghasilkan energi, dan pergerakan kepala miosin Terjadi tumpang tindih miofilamen sehingga sarkomer memendek yang menghasilkan kontraksi otot. Sumber: Junqueira LC, Carneiro J, $2005 .^{6}$

Bila ion $\mathrm{Ca}^{2+}$ terikat pada troponin $\mathrm{C}$, terjadi perubahan konfigurasi filamen tipis dan tempat aktif pada aktin terbuka sehingga aktin dapat berikatan dengan miosin melalui jembatan silang (cross bridge) (Gambar 5).

Pada kepala miosin terdapat enzim ATP-ase yang menghidrolisis ATP menjadi ADP dan P. Reaksi ini memindahkan energi dari ATP ke kepala miosin sehingga kepala miosin secara spontan berikatan dengan tempat aktif pada aktin, yang menghasilkan power stroke kontraksi. Filamen tipis meluncur melewati filamen tebal menuju zone $\mathrm{H}$ sehingga terjadi pemendekan sarkomer dan serat otot.
Pada relaksasi otot terjadi penguraian asetilkolin sehingga aksi potensial terhenti. Kerja pompa transpor aktif $\mathrm{Ca}^{2+}$ memasukkan ion $\mathrm{Ca}^{2+}$ ke dalam RS. Saluran pelepas $\mathrm{Ca}^{2+}$ pada $\mathrm{RS}$ tertutup. Dengan turunnya konsentrasi $\mathrm{Ca}^{2+}$ sarkoplasma maka ikatan i9on ini dengan troponinC terlepas, kompleks tropomiosintroponin kembali ke posisi semula menutupi tempat aktif pada aktin. Jembatan silang tidak terbentuk dan filamen tipis kembali ke tempat semula.

\section{SIMPULAN}

Jaringan otot rangka tersusun atas serat-serat otot yang berjalan sejajar dengan miofibrilnya yang terdiri atas unit kontraktil yang lebih kecil yaitu miofilamen tebal dan tipis. Sistem membran terdiri atas sarkolema, tubulus $\mathrm{T}$, dan retikulum sarkoplasma beserta sisternanya. Sarkolema merupakan tempat paling awal terjadinya depolarisasi yang dihantarkan ke dalam serat otot melalui tubulus T, struktur kaki pada daerah triad, dan sisterna terminalis yang selanjutnya memicu pelepasan ion $\mathrm{Ca}^{2+}$ dari retikulum sarkoplasma. Ion $\mathrm{Ca}^{2+}$ merupakan kunci pemicu untuk pembentukan jembatan silang yang mengawali suatu kontraksi otot rangka.

\section{DAFTAR PUSTAKA}

1. Al-Qusairi L, Laporte J. T-tubule biogenesis and triad formation in skeletal muscle and implication in human diseases. [cited 2014 Oct 3]. Available from: http://www.skeletalmusclejournal.com/ content/1/1/26

2. Copenhaver WM, Bunge MB. Muscle. Bailey's Textbook of Histology (Sixteenth Edition). Baltimore: Williams \& Wilkins, 1971.

3. Fawcett DW. Muscular Tissue. A Textbook of Histology (Twelfth Edition). New York: Chapman \& Hall, 1994.

4. Ferguson A, Schwartz HW, Armstrong CF. Subunit structure of junctional feet in triads of skeletal muscle: A freeze- 
drying, rotary-shadowing study. The Journal of Cell Biology. 1984;99:173542.

5. Gartner P. Hiatt JL. Muscle. Color Textbook of Histology (Third Edition). Philadelphia: Saunders Elsevier, 2007.

6. Junqueira LC, Carneiro J. Muscle Tissue. Basic Histology Text \& Atlas (Seventh Edition). New York, McGraw-Hill, 2005.

7. Leeson RC, Leeson TS, Paparo AA. Muscle. Textbook of Histology (Fifth Edition). Philadelphia: WB Saunders, 1985.

8. McPherson PS, Campbell KP. The ryanodine receptor/ $/ \mathrm{Ca}^{2+}$ release channel. The Journal of Biological Chemistry. 1993;268:19.

9. Mescher AL. Muscle tissue. Junqueira's Basic Histology Text \& Atlas (Twelfth Edition). New York: Mc GrawHill, 2010.
10. Ross MH, Wojciech P. Muscle tissue. Histology A Text and Atlas with Correlated Cell and Molecular Biology (Sixth Edition). Philadelphia: Lippincott Williams \& Wilkins Wolters Kluwer, 2011.

11. Saito A, Inui M, Radermacher M, Frank J, Fleischer S. Ultrastructure of the calcium release channel of sarcoplasmic reticulum. The Journal of Cell Biology. 1998;107:211-9.

12. Stokes DL, Wagenknecht T. Calcium transport across the sarcoplasmic reticulum. Structure and function of $\mathrm{Ca}^{2+}$-ATPase and the ryanodine receptor. Eur J Biochem. 2000; 267:5274-9.

13. Tortora GJ, Derrickson B. Muscular tissue. Principles of Anatomy \& Physiology (Thirteenth Edition). Danvers: John Wiley \& Sons Inc, 2012. 